\title{
ОСОБЛИВОСТІ ЗАСТОСУВАННЯ МОДЕЛІ УПРАВЛІННЯ ЗА СЛАБКИМИ СИГНАЛАМИ
}

\author{
FEATURES OF APPLICATION \\ OF WEAK SIGNAL CONTROL MODEL
}

\author{
Милько Інна Петрівна \\ кандидат економічних наук, доцент, \\ Волинський національний університет імені Лесі Українки \\ ORCID: https://orcid.org/0000-0001-9723-2614
}

\author{
Mylko Inna \\ Lesya Ukrainka Volyn National University
}

\begin{abstract}
Стаття присвячена визначенню особливостей застосування моделі управління за слабкими сигналами. Визначено сутність концепції управління за слабкими сигналами, актуальність її застосування у сучасних динамічно змінних умовах. Пояснено застосування матриці оцінки рівня нестабільності зовнішнього середовища при виборі виду стратегічного управління. Запропоновано методики для моніторингу зовнішнього середовища підприємства та орієнтовні цільові параметри оцінки слабких сигналів зміни умов зовнішнього і внутрішнього середовищ підприємства за окремими соерами прояву. Виділено два варіанти відповіді на зовнішні сигнали: реакція, що базується на регулярному плануванні та ситуаційна реакція на надзвичайні зміни. Описано етапи фрормування інформаційно-аналітичної системи на підприємстві.

Ключові слова: модель управління за слабкими сигналами, слабкі сигнали, види стратегічного управління, цільові параметри оцінки слабких сигналів, інфрормаційно-аналітична система.
\end{abstract}

Стаття посвящена определению особенностей использования модели управления за слабыми сигналами. Определено значение концепции управления за слабыми сигналами, актуальность ее использования в современных динамических условиях. Объяснено использование матрици оценки уровня нестабильности внешней среды в условиях выбора вида стратегического управления. Предложены методики для мониторинга внешней среды предприятия, а также ориентировочные целевые параметры оценки слабых сигналов смены условий внешней и внутренней среды предприятия за отдельными сферами проявления. Виделено два варианта ответа на внешние сигналы: реакция, що основывается на регулярному планировании, ситуационная реакция на серйозные изменения. Описано етапы формирования информационно-аналитической системы на предприятии.

Ключові слова: модель управления за слабыми сигналами, слабые сигналы, виды стратегического управления, целевые параметры оценки слабых сигналов, информационно-аналитическая система.

The article is devoted to the definition of the peculiarities of the application of the control model for weak signals. The essence of the concept of control by weak signals, the relevance of its application in modern dynamically changing conditions is determined. The concept of weak signal management for each level of instability provides an appropriate type of strategic management. At the first stage, the factors are assessed qualitatively on the following grounds: the familiarity of events, the pace of change and predictability; in the second stage, a matrix is built, according to which each qualitative feature is translated into points. The application of the matrix for estimating the level of instability of the external environment when choosing the type of strategic management is explained. Methods for monitoring the external environment of the enterprise are indicated: STEP-analysis, STEEPLE-analysis, SWOT-analysis, analysis of M. Porter's five competitive forces, benchmarking, PIMS-analysis, scenario analysis, early warning system. Approximate target parameters of estimation of weak signals of change of conditions of external and internal environments of the enterprise on separate spheres of display are offered: personnel, technical and technological, industrial, innovative, information, ecological, political, economic, social, technological spheres. There are two options for responding to external signals: a response based on regular planning, a situational response to extraordinary changes. The model of control on weak signals is possible only under the condition of accurately constructed information-analytical system at the enterprise. The stages of formation of the information-analytical system at the enterprise are described: definition of objects of internal and external diagnostics; Establishment of limit limits 
of indicators and admissible intervals for their change; definition of analytical tasks for services of information-analytical activity; establishing proper communication between analysts and managers; generalization of the received analytical information and development of offers and recommendations.

Keywords: weak signal control model, weak signals, types of strategic control, target parameters for weak signal estimation, information-analytical system.

Постановка проблеми. Українські суб'єкти господарювання щодня зустрічаються 3 новими викликами, які вимагають миттєвої реакції, пошуків вирішення проблем у нових та нестандартних ситуаціях, які іноді неможливо передбачити. Досить часто можна почути думку про те, що стратегічне планування неактуальне, тому що, закінчивши розробку стратегії, потрібно її змінювати, тому що попередня уже неактуальна. Ми ж переконані, що стратегічне управління $€$ незамінним інструментом для будь-якого суб'єкта господарювання, проте вимагає особливого підходу та використання нових моделей стратегічного управління.

Сучасні моделі повинні забезпечити достатній рівень гнучкості суб'єктів господарювання, створити умови та механізм для раннього виявлення змін та їх попередження. Тому варто використати модель управління за слабкими сигналами.

Аналіз останніх досліджень і публікацій. Управління за слабкими сигналами $є$ достатньо новою, проте теоретичні та прикладні засади його здійснення знайшли відображення у дослідженнях багатьох вітчизняних та зарубіжних науковців: І. Ансофрфа, М.€. Адамів, І.О. Кузьміна, М.І. Копитко, О. Мельник, Г.В. Єорімова, Л.М. Романюк, О.Г. Цмоць, О.І. Чевганова та інших. Зокрема у наукових працях цих вчених розглянуто тенденції та методологічних підходи до стратегічного управління, адаптація українських компаній д змін [2], запропоновано засоби моделювання фрункціонування підприємств, оперативного аналізу економічних даних, оцінювання сигналів впливу на підприємство $[4 ; 5 ; 6]$, розроблені підходи до планування за слабкими сигналами в антисипативному управлінні 3 використанням мережевої моделі [9], розроблено принципи антисипативного управління, що ґрунтується на слабких сигналах.

Метою статті $\epsilon$ розглянути особливості застосування моделі управління за слабкими сигналами, обґрунтувати цільові параметри оцінки слабких сигналів зміни умов зовнішнього і внутрішнього середовищ підприємства.

Виклад основного матеріалу дослідження. Непередбачувані та динамічні зміни в усіх сорерах суспільно-економічного життя стали підставою для пошуку нових моделей стратегічного управління та вдосконалення уже розроблених моделей. Зокрема, в умовах високого ступеню невизначеності та ризиковості на особливу увагу заслуговує модель управління за слабкими сигналами (за I. Ансофрфом) [1].

Модель управління за слабкими сигналами базується на припущенні про те, що будь які несприятливі, несподівані явища або несподівана перспектива появи можливостей для компанії не виникають раптово, а такі події можна спрогнозувати за сигналами-провісниками або, так званими «слабкими сигналами» за термінологією I. Ансофрфа [2; 3].

I. Ансофрфр, як розробник концепції, та ії̈ прихильники «слабкими сигналами» вважають ранні і неточні ознаки настання важливих подій, які з часом стають достовірнішими та перетворюються на сильні сигнали. Запропонована модель стратегічного управління підприємствами орієнтована на прийняття рішень в режимі реального часу, в мовах нестабільності зовнішнього середовища. У цьому випадку важливо не пропустити передвісники додаткових можливостей, забезпечити створення механізму пристосування до змін та сорормувати запас гнучкості, збільшити час для того, щоб прийняти і реалізувати управлінське рішення, щоб попередити загрози, що наближаються, і оперативно використати ймовірні можливості [4].

Концепція І. Ансофрфа передбачає, що на першому етапі чинники оцінюються якісно за такими ознаками: звичність подій, темп змін та передбачуваність; на другому етапі будується матриця, за якою кожна якісна ознака переводиться у бали (рис. 1).

Автор концепції управління за слабкими сигналами для кожного рівня нестабільності розробив відповідний вид стратегічного управління. Звичайно, чим вищий рівень непередбачуваності, тим більше зусиль необхідно потрібно прикласти для вибору адекватного виду стратегічного управління. У той же час I. Ансофрф передбачив, що зреагувати на зміни за високо рівня нестабільності потрібно за досить короткий відрізок часу [2; 7]. Зокрема, якщо ступінь нестабільності відносно невисокий, то пропонується до використання управління на основі екстраполяції тенденцій (довгострокове планування); якщо ступінь 


\begin{tabular}{|c|c|c|c|c|c|c|c|}
\hline \multirow{3}{*}{$\begin{array}{c}\text { Ознака } \\
\begin{array}{c}\text { Звичність } \\
\text { події }\end{array} \\
\end{array}$} & \multicolumn{7}{|c|}{ Сила сигналу } \\
\hline & Стабільність & $\begin{array}{l}\text { Реакція } \\
\text { на зміни }\end{array}$ & Пере & чення & Досліджен & & Творчість \\
\hline & \multicolumn{2}{|r|}{$\begin{array}{r}\mathrm{y} \\
\text { екс }\end{array}$} & $\begin{array}{l}\text { ках } \\
\text { оляції } \\
\text { ду }\end{array}$ & \multicolumn{2}{|c|}{$\begin{array}{l}\text { Неочікувані, ті, що } \\
\text { мають аналогії }\end{array}$} & \multicolumn{2}{|c|}{$\begin{array}{l}\text { Неочікувані та } \\
\text { повністю нові }\end{array}$} \\
\hline Темпи змін & \multicolumn{2}{|c|}{$\begin{array}{c}\text { Повільніший, ніж реакція } \\
\text { організації }\end{array}$} & \multicolumn{3}{|c|}{$\begin{array}{c}\text { Відповідає реакції } \\
\text { організації }\end{array}$} & \multicolumn{2}{|c|}{$\begin{array}{l}\text { дший за реакцію } \\
\text { організації }\end{array}$} \\
\hline $\begin{array}{c}\text { Передбачу- } \\
\text { ваність }\end{array}$ & $\begin{array}{c}\text { За аналогією } 3 \\
\text { минулим }\end{array}$ & $\begin{array}{r}Ш \\
\text { екстр }\end{array}$ & $\begin{array}{l}\text { ом } \\
\text { оляції }\end{array}$ & $\begin{array}{r}\text { Пер } \\
\text { значні } \\
\text { нові }\end{array}$ & $\begin{array}{l}\text { бачувані } \\
\text { роблеми та } \\
\text { ожливості }\end{array}$ & & $\begin{array}{l}\text { Часткова } \\
\text { едбачуваніс } \\
\text { за слабкими } \\
\text { ггналами та } \\
\text { тередбачува } \\
\text { ні зміни }\end{array}$ \\
\hline $\begin{array}{c}\text { Шкала } \\
\text { нестабіль- } \\
\text { ності }\end{array}$ & 1 & 2 & & 3 & 4 & & 5 \\
\hline
\end{tabular}

Рис. 1. Матриця оцінки рівня нестабільності зовнішнього середовища (за І. Ансоффом)

Джерело: [1]

нестабільності має середнє значення, то рекомендованим $€$ управління на основі передбачення змін (стратегічне планування, вибір стратегічних позицій); якщо ступінь нестабільності зовнішнього середовища є високим, то застосовується управління на основі гнучких експертних рішень (ранжування стратегічних завдань; управління за слабкими сигналами; управління в умовах стратегічних несподіванок). Загалом варто зауважити, що пропонована I. Ансофрфом методика не враховує увесь комплекс чинників зовнішнього середовища.

Модель управління за слабкими сигналами буде дієвою, якщо розробити ефективну систему збору та обробки інформації, що дозволить відслідковувати можливі зміни у зовнішньому та внутрішньому середовищах підприємства. Щоб спрогнозувати чи передбачити наслідки змін для підприємства, необхідно постійно збирати та аналізувати відомості про сприятливі і несприятливі тенденції, динаміку зміни визначених параметрів. Моніторинг зовнішнього середовища можна здійснювати, використовуючи такі традиційні методики, як STEP-аналіз, STEEPLE-аналіз, SWOT-аналіз, аналіз п'яти конкурентних сил M. Портера, бенчмаркінг, PIMS-аналіз, сценарний аналіз, система раннього попередження. Ми пропонуємо, відібрати орієнтовні цільові параметри оцінки слабких сигналів зміни умов зовнішнього і внутрішнього середовищ підприємства (табл. 1). Такі цільові параметри можуть змінюватись і доповнюватись залежно від виду економічної діяльності підприємства, поставлених цілей, конкурентного середовища, умов функціонування тощо.

Цільові параметри, що використовуються для оцінки зміни умов зовнішнього і внутрішнього середовищ підприємства, не можуть бути сталими, а повинні переглядатись залежно від поставлених цілей та нових умов фрункціонування.

На підставі зміни цільових параметрів, прогнозування змін сильних і слабких сторін підприємства коригуються стратегічні і тактичні плани [6]. Можна виділити два варіанти відповіді на зовнішні сигнали:

реакція, що базується на регулярному плануванні (в організаційно-економічний механізм поточного управління підприємством закладені механізми протидії зовнішнім загрозам);

ситуаційна реакція на надзвичайні зміни, коли установлений порядок дій скасовується і для прийняття термінових дій виробляються «цільові команди».

Отож модель управління за слабкими сигналами можлива лише за умови чітко побудованої інфооммаційно-аналітичної системи на підприємстві, процес розробки якої повинен складатися з таких етапів [1; 5]:

Формування інформаційно-аналітичної системи на підприємстві передбачає такі етапи:

1. Визначення об'єктів внутрішньої (фрінансова, виробнича, збутова, організаційна діяльність) та зовнішньої діагностики (макрота мікросередовище).

2. Формування переліку індикаторів раннього попередження, які допоможуть виявити потенційні небезпеки. 
Таблиця 1

\section{Орієнтовні цільові параметри оцінки слабких сигналів зміни умов зовнішнього і внутрішнього середовищ підприємства}

\begin{tabular}{|c|c|}
\hline Сорери прояву & Цільові параметри оцінки \\
\hline \multicolumn{2}{|r|}{ Внутрішнє середовище } \\
\hline Фінансова сорера & $\begin{array}{l}\text { Показники фрінансової автономії, ліквідності і платоспроможності, } \\
\text { ділової активності, рентабельності, вартість кредитних ресурсів, } \\
\text { курс акцій, відмови кредитних установ у залученні коштів, } \\
\text { невиконання фрінансових зобов'язань }\end{array}$ \\
\hline Кадрова сорера & $\begin{array}{l}\text { Плинність персоналу, витрати на навчання персоналу, організаційна } \\
\text { структура, зміни у кадровому потенціалі підприємства (рівень освіти, } \\
\text { кваліфікації, досвіду роботи), продуктивність праці, заробітна плата } \\
\text { за категоріями персоналу, конфрліктні ситуації, зміни інтелектуального } \\
\text { потенціалу, зміни умов праці }\end{array}$ \\
\hline $\begin{array}{l}\text { Техніко-технологічна } \\
\text { сорера }\end{array}$ & $\begin{array}{l}\text { Середній термін експлуатації основних засобів (ОЗ) за видами, рівень } \\
\text { зносу О3, фрондоозброєність, техноозброєність, енергоозброєність } \\
\text { праці }\end{array}$ \\
\hline Виробнича сорера & $\begin{array}{l}\text { Рівень використання корпоративних ресурсів, ефективність } \\
\text { логістичної системи, рівень диверсифрікації виробництва, ритмічність } \\
\text { виробництва }\end{array}$ \\
\hline Інноваційна ссрера & $\begin{array}{l}\text { Рівень морального зносу ОЗ, використання застарілих технологій } \\
\text { у виробництві та управлінні, виробництво продукції із параметрами, } \\
\text { які поступаються параметрам продукції конкурентів }\end{array}$ \\
\hline Інфрормаційна сорера & Рівень комп'ютеризації, оцінка електронного документообігу \\
\hline Екологічна сорера & $\begin{array}{l}\text { Шкідливі викиди в навколишнє середовище, ймовірність виникнення } \\
\text { техногенних аварій, випуску продукції, яка містить шкідливі речовини }\end{array}$ \\
\hline \multicolumn{2}{|r|}{ Зовнішнє середовище } \\
\hline Політична сорера & $\begin{array}{l}\text { політична стабільність, політична спрямованість держави, міжнародні } \\
\text { зв'язки з іншими країнами }\end{array}$ \\
\hline Економічна ссрера & $\begin{array}{l}\text { рівень інфрляції, курс валют, рівень доходів населення, рівень } \\
\text { безробіття, інвестиційний клімат, ціни на виробничі ресурси, } \\
\text { експортно-імпортна політика }\end{array}$ \\
\hline Соціальна сфрера & $\begin{array}{l}\text { чисельність та структура населення, рівень життя, зміна смаків } \\
\text { та переваг споживачів }\end{array}$ \\
\hline Технологічна сорера & $\begin{array}{l}\text { державна політика у сорері науки і науково-технічної діяльності, } \\
\text { темпи розроблення прогресивних технологій ведення господарства, } \\
\text { темпи розроблення нової продукції, нові відкриття, автоматизація } \\
\text { технологічних процесів, адаптація нових технологій, ступінь легкості } \\
\text { отримання інфрормації про нові технології. }\end{array}$ \\
\hline \multicolumn{2}{|r|}{ Форс-мажорні обставини } \\
\hline
\end{tabular}

3. Встановлення граничних меж індикаторів та допустимих інтервалів для їх зміни (зони безпеки, критичні точки, точки неповернення).

4. Визначення аналітичних завдань для служб інформаційно-аналітичної діяльності.

5. Налагодження належного комунікативного зв'язку між аналітиками та керівниками, яким призначена інформація і які повинні реагувати на тенденції, що змінюються.

6. Узагальнення одержаної аналітичної інорормація та розробка пропозицій та рекомендацій щодо використання конкретних сильних сторін та зменшення негативного впливу зовнішніх загроз, підготовка кількох проектів управлінських рішень [1; 5].
Висновки. Для того щоб своєчасно реагувати на сигнали, що надходять як ззовні, так і 3 внутрішнього середовища, використовуючи управління за слабкими сигналами повинно бути організоване спостереження за великою кількістю параметрів, що $є$ індикаторами ефективності діяльності підприємства.

Отже, для ефективного застосування моделі управління за слабкими сигналами важливо виділити найсуттєвіші індикатори, які впливають на підприємство, а також напрацювати методику визначення впливу передбачуваних змін та розробити механізм використання потенційних можливостей та нейтралізації можливих загроз. 


\section{СПИСОК ВИКОРИСТАНИХ ДЖЕРЕЛ:}

1. Ансоффф И. Стратегическое управление. Москва : Экономика, 1989. 520 с.

2. Романюк Л.М. Сучасні тенденції стратегічного управління підприємством. Наукові праці КНтУ. Економічні науки. 2009. Випуск 15. С. 102-106.

3. Безгінова Л.І., Забродська Л.Д., Швед С.А., Яроцька О.Г. Моделі стратегічного управління підприємством. URL: http://nbuv.gov.ua/UJRN/esprstp_2014_2_32

4. Цмоць О.І. Особливості стратегічного управління підприємствами з використанням слабких сигналів. URL: http://nbuv.gov.ua/UJRN/Tatrv_2012_4(1)_21

5. Цмоць О.І. Системи раннього попередження та реагування для стратегічного управління машинобудівним підприємством у режимі реального часу. URL: http://zbirnuk.bukuniver.edu.ua/issue_articles/32.pdf

6. Єфрімова Г.В. Виявлення та раннє попередження загроз в поточному управлінні підприємством. Вісник ХНАУ ім. В.В. Докучаєва. Серія «Економічні науки». № 4. 2018. С. 14-21.

7. Чевганова В., Гайдучок М. Оцінка нестабільності зовнішнього середовища сільськогосподарського підприємства. Глобальні та національні проблеми економіки. 2017. Випуск 19. С. 291-295.

8. Копитко М. І. Виявлення слабких сигналів середовища фуункціонування як запорука формування високого рівня економічної безпеки промислових підприємств. Економіка та держава. 2014. № 11. С. $24-27$.

9. Тарасова Г.О. Забезпечення планування роботи з сигналами в антисипативному управлінні розвитком промислового підприємства. Економіка і суспільство. 2018. Випуск 18. С. 556-564.

\section{REFERENCES:}

1. Ansoff I. (1989) Stratehycheskoe upravlenye. Moscow: Ekonomyka, 520 p. (in Russian)

2. Romaniuk L.M. (2009) Suchasni tendentsii stratehichnoho upravlinnia pidpryiemstvom. Naukovi pratsi KNTU. Ekonomichni nauky, no. 15, pp. 102-106. (in Ukrainian)

3. Bezghinova L.I., Zabrodska L.D., Shved S.A., Yarotska O.H. Modeli stratehichnoho upravlinnia pidpryiemstvom. URL: http://nbuv.gov.ua/UJRN/esprstp_2014_2_32

4. Tsmots O.I. Osoblyvosti stratehichnoho upravlinnia pidpryiemstvamy z vykorystanniam slabkykh syhnaliv. URL: http://nbuv.gov.ua/UJRN/Tatrv_2012_4(1)_21

5. Tsmots O.I. Systemy rannoho poperedzhennia ta reahuvannia dlia stratehichnoho upravlinnia mashynobudivnym pidpryiemstvom u rezhymi realnoho chasu. URL: http://zbirnuk.bukuniver.edu.ua/issue_articles/32.pdf

6. Efimova H.V. (2018) Vyiavlennia ta rannie poperedzhennia zahroz v potochnomu upravlinni pidpryiemstvom. Visnyk KhNAU im. V.V. Dokuchaieva. Seriia «Ekonomichni nauky», no. 4, pp. 14-21. (in Ukrainian)

7. Chevhanova V., Haiduchok M. (2017) Otsinka nestabilnosti zovnishnoho seredovyshcha silskohospodarskoho pidpryiemstva. Hlobalni ta natsionalni problemy ekonomiky, no. 19, pp. 291-295. (in Ukrainian)

8. Kopytko M. (2014) Vyiavlennia slabkykh syhnaliv seredovyshcha funktsionuvannia yak zaporuka formuvannia vysokoho rivnia ekonomichnoi bezpeky promyslovykh pidpryiemstv. Ekonomika ta derzhava, no. 11, pp. 24-27. (in Ukrainian)

9. Tarasova H.O. (2018) Zabezpechennia planuvannia roboty z syhnalamy $v$ antysypatyvnomu upravlinni rozvytkom promyslovoho pidpryiemstva. Ekonomika i suspilstvo, no. 18, pp. 556-564. (in Ukrainian) 